\title{
Peran Guru Pendidikan Agama Islam Dalam Mengantisipasi Dampak Penggunaan Media Sosial Bagi Siswa Sekolah Menengah Pertama
}

\author{
Ismail \\ Program Studi Pendidikan Agama Islam, \\ Fakultas Tarbiyah dan Ilmu keguruan, IAIN Palopo \\ Email: ismailbas959@gmail.com
}

\begin{abstract}
This study aims to describe the existence of social media on student behavior and the inhibiting factors of PAI teachers in various social media at North Belopa State Middle School. This research is qualitative research that uses pedagogical, psychological, sociological, and theological normative approaches. Data sources are primary data sourced from principals, PAI teachers, and students through interviews, while data in the form of existing documents with research. The results of the study show that in the role of the teacher in using social media in junior high school students in the sub-district as follows: 1. Dutch Middle School students use social media as a place to show the outside world. Everyone is competing to display and make branding about the World World. There is nothing that can be done for others and 2. As for the PAI teacher's inhibitors in various social media at the North Belopa State Middle School, they are not working with teachers and parents in using social media. Community environment (association) association of students outside the school is also very large on the behavior and behavior of students in everyday life. Ineffective regulations made by schools.
\end{abstract}

Keywords: Teacher's Role; Islamic education; Social media.

\begin{abstract}
Abstrak
Penelitian ini bertujuan untuk mendeskripsikam eksistensi media sosial terhadap perilaku siswa dan faktor-faktor penghambat guru PAI dalam mengantisipasi dampak media sosial di SMP Negeri Belopa Utara. Penelitian ini adalah penelitian kualitatif yang menggunakan pendekatan pedagogis, psikologis, sosiologis, dan teologis normatif. Sumber data yaitu data primer bersumber dari kepala sekolah, guru PAI, dan siswa melalui wawancara, sedangkan data sekunder diambil dari dokumen yang ada kaitannya dengan penelitian. Hasil penelitian menunjukkan bahwa dalam peran guru pendidikan agama dalam mengantisipasi dampak penggunaan media sosial bagi siswa SMP Negeri di kecamatan belopa utara sebagai berikut: 1. Siswa SMP Negeri Kecamatan Belopa Utara memanfaatkan media sosial sebagai ajang untuk menunjukkan keberadaan dirinya kepada dunia luar. Setiap orang berlomba-lomba untuk menampilkan dan membuat branding tentang dirinya kepada dunia luar. Tidak jarang pula bahkan seseorang bisa bertindak berlebihan untuk sekedar menunjukan eksistensi dirinya kepada orang lain, 2. adapun yang menjadi penghambat guru PAI dalam mengantisipasi dampak media sosial di SMP Negeri Belopa Utara yaitu kurang kerja sama guru dan orang tua dalam mengantisipasi penggunaan media sosial. Lingkungan masyarakat (pergaulan) pergaulan dari siswa di luar sekolah juga sangat berpengaruh besar terhadap tingkah laku dan perilaku siswa dalam kehidupan sehari-hari. Kurang efektifnya peraturan yang dibuat sekolah.
\end{abstract}

Kata Kunci: Peran Guru; Pendidikan Agama Islam; Media Sosial 


\section{PENDAHULUAN}

Siswa sebagai objek dan pelaku pendidikan merupakan bagian dari komponen pendidikan yang mengalami perubahan perilaku karena perubahan lingkungan yang terjadi disekitarnya. Kehadiran HP terutama yang memiliki aplikasi lengkap sangat mempengaruhi kehidupan siswa. Aplikasi tersebut dapat dijadikan sebagai alat untuk mengembangkan potensi diri dengan menggunakan fasilitas aplikasi yang tersedia. Namun juga dapat dijadikan sebagai alat untuk merusak kepribadian siswa jika salah didalam menggunakan, apapun jenis aplikasinya.

Berbagai macam dampak yang bisa ditimbulkan oleh eletronik yang dalam hal ini ialah dunia maya. Oleh sebab itu, disini penulis akan mencoba untuk meneliti bagaimana cara para guru PAI dalam mengantisipasi dampak buruk yang akan ditimbulkan media sosial tersebut terutama bagi para siswa, terutama dalam hal-hal yang berkaitan dengan perilaku siswa.

Kenakalan sebenarnya menunjuk pada perilaku yang berupa penyimpangan atau pelanggaran pada norma yang berlaku, dan ditinjau dari segi hukum kenakalan merupakan pelanggaran terhadap hukum yang belum bisa dikenai hukum pidana sehubungan dengan usiannya. Perilaku menyimpang pada remaja pada umumnya merupakan "kegagalan sistem kontrol diri". Karena kenakalan itu muncul pada jenjang sekolah dan integrasi yang paling bisa dirasakan adalah antara guru dengan murid. Problem tersebut sering kali terjadi dalam bentuk kesulitan dalam menghadapi pelajaran disekolah, baik dalam lisan, tulisan maupun penyelesaian tugas. Remaja yang mengalami problem disekolah pada umumnya mengemukakan keluhan bahwa mereka tidak ada minat terhadap pelajaran dan bersikap acuh tak acuh, prestasi belajar menurun kemudian timbul sikap-sikap dan perilaku yang tidak diinginkan seperti membolos, melanggar tata tertib, menentang guru, berkelahi. Pekerjaan yang menunggu untuk para guru adalah dapat memilih dan menggunakan tehnik mengajar yang dapat meningkatkan peran serta (partisipasi) siswa dalam kelas.

Nikmah mengungkapkan bahwa Siswa akan lebih berprestasi bila dapat meminimalkan waktu dalam penggunaan cellularphone yang tidak penting, dan mengalihkannya dengan cara mengisi hal-hal positif. Siswa akan lebih berprestasi jika dapat mengurangi waktu untuk bermain-main (menggunakan cellularphone) dan mengisi waktu luangnya untuk membaca buku atau kegiatan positif lainnya. Yang membedakan antara penelitian tersebut dengan penelitian ini terletak pada obyek penelitiannya, yaitu prestasi belajar siswa sedangkan dalam penelitian ini yaitu moral dan pendidikan karakter siswa. ${ }^{1}$

\footnotetext{
${ }^{1}$ Nikmah, "Dampak Penggunaan Cellularphone Terhadap Prestasi Siswa", E-Jurnal Volume 5, (Surabaya: Dinas Pendidikan Kota Surabaya, 2013). h. 8.
} 
Juditha, "ada hubungan antara penggunaan dengan perilaku remaja baik itu secara positif maupun negatif". ${ }^{2}$

Heru Wahyu Pamungkas, "Interaksi orang tua dengan anak dalam menghadapi dampak teknologi merupakan media yang ampuh sebagai media pendidikan bagi anak, dan seharusnya menjadi priorotas utama. ${ }^{3}$

\section{KERANGKA TEORI}

\section{Pendidikan Agama Islam}

Pendidikan agama Islam merupakan usaha secara sadar dalam memberikan bimbingan kepada anak didik untuk berperilaku sesuai dengan ajaran Islam dan memberikan pelajaran dengan materi-materi tentang pengetahuan Islam. ${ }^{4}$

Pedoman pengembangan standar kompetensi dan kompetensi dasar menjelaskan bahwa mata pelajaran PAI di sekolah memuat materi Alquran dan Hadits, Aqidah, Akhlak, Fiqih, dan Tarikh. Ruang lingkup tersebut menggambarkan materi PAI yang mencakup perwujudan keserasian, keselarasan, dan keseimbangan hubungan manusia dengan Allah swt, diri sendiri, sesama manusia, makhluk lainnya, maupun lingkungannya. ${ }^{5}$

Sedang menurut M. Arifin adapun ruang lingkup Pendidikan Agama Islam meliputi:

a. Tarbiyah jismiyyah, yaitu segala rupa pendidikan yang wujudnya menyuburkan dan menyehatkan tubuh serta menegakkannya, supaya dapat mengatasi kesukaran yang dihadapi dalam pengalamannya.

b. Tarbiyah aqliyah, yaitu sebagaimana rupa pendidikan dan pelajaran yang hasilnya dapat mencerdaskan akal menajamkan otak semisal ilmu berhitung.

c. Tarbiyah adabiyah, segala sesuatu praktek maupun teori yang dapat meningkatkan budi dan meningkatkan perangai. Tarbiyah adabiyah atau pendidikan budi pekerti/akhlak dalam ajaran Islam merupakam salah satu ajaran pokok yang mesti diajarkan agar umatnya memiliki dan melaksanakan akhlak yang mulia sebagaimana yang telah dicontohkan oleh Rasulullah saw. ${ }^{6}$

Abdul Majid dan Dian Andayani, menjelaskan bahwa materi pendidikan agama Islam berdasarkan rumusan dari pokok ajaran Islam meliputi aqidah (keimanan),

${ }^{2}$ Christiany Juditha, "Hubungan Penggunaan Status Jejaring Sosial Facebook terhadap Perilaku Remaja di Kota Makasar”, Jurnal Penelitian IPTEK-KOM, Vol 13 No. 1, Juni 2011, (Yogyakarta: Kompasiana, 2001), h. 1.

${ }^{3}$ Heru Wahyu Pamungkas, Interaksi Orang Tua dengan Anak dalam Menghadapi Teknologi Komunikasi Internet (Studi Pada SMA Rahadi Usman), Jurnal (Pontianak: Tesis PMIS Untan, 2014), h. 1

4 Ahmad Qodri Azizy, Islam dan Permasalahan Sosial; Mencari Jalan Keluar (Yogyakarta: Pustaka Pelajar, 2003), h. 22

${ }^{5}$ Depag RI, Direktorat Jendral Pembinaan Kelembagaan Agama Islam, Direktorat Madrasah dan Pendidikan Agama Islam pada Sekolah Umum, KBK Kegiatan Pembelajaran Qur'an Hadits, (Jakarta: Direktorat Jendral Pembinaan Kelembagaan Agama Islam, 2003), h. iii.

${ }^{6}$ M. Arifin, Kapita Selekta Pendidikan (Umum dan Agama), (Jakarta:Toha Putra, 2003) h. 70. 
syari'ah (keIslaman) dan akhlak (budi pekerti). Ketiga kelompok ilmu agama itu kemudian dilengkapi dengan pembahasan dasar hukum Islam yaitu al-Qur'an dan Hadis serta ditambah lagi dengan sejarah Islam (tarikh). ${ }^{7}$

\section{Peran Guru}

Pendidikan adalah salah satu proses yang bertujuan membentuk pola perilaku. Misalnya pendidikan kemiliteran, pendidikan kewiraswastaan, pendidikan agama dan sebagainya. Proses itu biasanya membutuhkan peran pendidik, tetapi juga bisa mendidik diri sendiri setelah berjumpa dengan pengalaman mendidik. Oleh karena itu, pendidikan agama lebih menekankan pada pemberian kesempatan agar seseorang mengalami sendiri atau pengalaman agama. Seorang pembina, pendidik mempunyai tanggung jawab sangat berat dalam membina anak-anak agar selalu melaksanakan perbuatan-perbuatan yang baik, bersikap sopan dan hormat kepada yang lebih tua, menghargai orang lain dan lain sebagainya. Cara meningkatkan pembinaan keberagamaan peserta didik menurut Muhammad Alim sebagai berikut:
a. Pendidikan dengan keteladanan
b. Pendidikan dengan adat kebiasaan
c. Pendidikan dengan nasihat
d. Pendidikan dengan memberikan perhatian
e. Pendidikan dengan memberikan hukuman. ${ }^{8}$
f. Orang tua sebagai cermin manusia berkepribadian Islam. ${ }^{9}$

Tugas guru Pendidikan Agama Islam adalah berusaha secara sadar untuk membimbing, mengajar, dan atau melatih peserta didik agar dapat: (1) meningkatkan keimanan dan ketaqwaannya kepada Allah swt yang telah ditanamkan dalam lingkungan keluarga, (2) menyalurkan bakat dan minatnya dalam mendalami bidang agama serta mengembangkannya secara optimal, sehingga dapat dimanfaatkan untuk dirinya sendiri dan dapat pula bermanfaat bagi orang lain, (3) memperbaiki kesalahan kesalahan, kekurangan-kekurangan dan kelemahan-kelemahan dalam keyakinan, pemahaman dan pengamalan ajaran Islam dalam kehidupan sehari-hari, (4) menangkal dan mencegah pengaruh negatif dari kepercayaan, faham atau budaya lain yang membahayakan dan menghambat perkembangan keyakinan peserta didik, (5) menyesuaikan diri dengan lingkungannya, baik lingkungan fisik maupun lingkungan sosial yang sesuai dengan ajaran Islam, (6) menjadikan ajaran Islam sebagai pedoman hidup untuk mencapai kebahagiaan hidup di dunia dan akhirat, dan (7) mampu memahami,

${ }^{7}$ Abdul Majid, Pendidikan Agama Islam Berbasis Kompetensi, (Bandung: Remaja Rosda Karya, 2005), h.79.

${ }^{8}$ Muhammad Alim, Pendidikan Agama Islam, Upaya Pembentukan Pemikiran dan Kepribadian Muslim, (Bandung: PT. Remaja Rosdakarya, 2006), h. 56

${ }^{9}$ Asmaun Sahlan, Mewujudkan Budaya Religius di Sekolah, h. 20. 
mengilmu pengetahuan agama Islam secara menyeluruh sesuai dengan daya serap peserta didik dan keterbatasan waktu yang tersedia. ${ }^{10}$

\section{Media Sosial}

Media sosial merupakan satu pengertian dari gabungan dua kata. Media dalam Kamus Umum Bahasa Indonesiadiartikan sebagai alat untuk berkomunikasi, perantara, dan penghubung. ${ }^{11}$ Sedangkan sosial artinya kehidupan manusia membutuhkan bantuan manusia yang lain untuk bertahan hidup dan melangsungkan kehidupannya dalam kerjasama sebagai kodrat manusia. ${ }^{12}$ Media sosial adalah demokratisasi media informasi yang meyediakan layanan informasi dan komunikasi yang terbuka secara luas melalui media internet secara global.

Unsur-unsur fundamental dalam media sosial adalah: pertama, media sosial melibatkan saluran sosial yang berbeda dan online menjadi utama. Kedua, media sosial berubah dari waktu ke waktu (artinya media sosial terus berkembang). Ketiga, media sosial adalah partisipatif (artinya) penonton atau pengguna diharapkan mampu memberikan komentar. ${ }^{13}$

Media sosial adalah bagian dari dunia teknologi yang terus berkembang. Teknologi yang berkembang tersebut adalah bagian dari modernitas kehidupan. Modernitas kehidupan termasuk menggunakan medeia sosial memiliki ciri-ciri yakni: ${ }^{4}$

a. Terbentuknya sikap individualitas, yakni kepentingan individu, orang bebas berpindah dan melakukan berbagai aktivitas, tanpa ikatan kelompok.

b. Deferensiasi dalam dunia ekonomi dan peluang tenaga kerja dan lain-lain.

c. Rasionalitas, artinya perhitungan dalam berbagai aspek.

d. Ekonomisme, yakni setiap kegiatan di dominasi oleh ekonomi, berusaha produktif dalam setiap kehidupan.

e. Perkembangan, cenderung memperluas jangkauannya. Inilah yang menjadi ciri khas dari globalisasi.

Orang Indonesia adalah salah satu pengguna terbesar yang ada di dunia. Di beberapa media sosial Indonesia menduduki peringkat atas dalam daftar pengguna media sosial paling aktif yang ada di dunia. Berikut adalah daftar media sosial yang digunakan oleh manusia di dunia yaitu: ${ }^{15}$

${ }^{10}$ Zubaedi, Desain Pendidikan Karakater, (Jakarta: Kencana, 2012), h. 274.

${ }^{11}$ Depdikbud, Kamus Besar Bahasa Indonesia, (Jakarta: Balai Pustaka, 1991), h. 243.

${ }^{12}$ Muhammad Rifai, Sosiologi Pendidikan, (Yogjakarta: Ar-Ruzz Media, 2011), h.15.

${ }^{13}$ Siti Nurjanah, Pengaruh Penggunaan Media Sosial Facebook terhadap Perilaku Cyberbullying pada Siswa SMAN 12 Pekan Baru, (Laporan Penelitian Ilmiah pdf, Jom FISIP Volum.1, No.2, Jurusan Ilmu Komunikasi-Prodi Ilmu Komunikasi-Fakultas Ilmu Sosial dan Politik UNIVERSITAS RIAU, 2014 ), http//www. Ejournal.com. Di akses pada 12 januari 2016.

${ }^{14}$ Piotr Sztompka, The Sociology of Social Change, diterjemahkan oleh Alimandan dengan judul: Sosiologi Perubahan Sosial, (Jakarta: Prenada, 2007), h. 85-86.

${ }^{15} \mathrm{http}$ ://sarungpreneur.com/inilah-macam-macam-sosial-media-yang-populer-di-dunia/, diakses pada 15 Januari 2015. 
a. Facebook

b. Twitter

c. Google Plus

d. Instagram

e. Pinterest

Adapun dampak positif dari menggunakan jejaring sosial atau media sosial adalah sebagai berikut:

1. Sosial media dapat dijadikan sebagai media untuk mengembangkan dunia bisnis yang dimiliki seseorang, sehingga tidak perlu berkeliling membawa barang yang diperdagangkan, tetapi cukup diperkenalkan secara detai melalui media sosial.

2. Dapat lebih aktif dan lebih berani menyampaikan gagasannya baik di dalam kelas maupun di luar kelas.

Adapun dampak negatif dari menggunakan jejaring sosial atau media sosial adalah sebagai berikut:

1. Kemajuan teknologi, termasuk media sosial akan menyebabkan manusia kehilangan kemanusiaannya yang mengarah pada kesenangan dan kenikmatan ketergantungan. ${ }^{16}$

2. Membuang waktu dan lupa waktu sehingga anak menjadi malas dalam belajar, dan menyebabkan malas dalam belajar, hingga berdampak buruk bagi perkembangan anak, intelegensi, emosional, dan sosialnya.

\section{METODE}

Penelitian ini adalah penelitian kkualitatif. penulis mengambil siswa SMP di kecamatan Belopa Utara sebagai lokasi penelitian. Alasan memilih tempat tersebut sebagai tempat penelitian karena budaya siswa dan sekolah yang menarik untuk diteliti, terutama dalam persoalan penggunaan media sosial pada siswa SMP. Disamping itu, lokasi sekolah ini merupakan daerah yang sudah memiliki kemajuan daerah sehingga proses akses internet atau jejaring sosial sangat mudah untuk dilakukan.

Subjek dalam peneltian tersebut adalah siswa SMP di kecamatan Belopa Utara yang menjadi pengguna media sosial dalam kehidupan sehari-harinya. Sehingga akan memiliki perubahan perilaku dalam bergaul, baik terhadap temannya, gurunya, masyarakat, dan keluarganya. Guru, pegawai, dan orang tua juga menjadi sumber informasi dalam penelitian ini, karena guru, pegawa, dan orang tua adalah orang-orang yang bertemu langsung dalam kehidupan siswa, dan menjadi orang-orang yang berinteraksi dengan para siswa.

16 Kharmim Zarkasyi Putro, Orang Tua Sahabat Anak dan Remaja, (Yogyakarta, Cerdas Pustaka, 2005), h.110. 
Pada penelitian ini peneliti menggunakan teknik pengumpulan data dengan observasi (pengamatan), interview dan dokumentasi. Untuk mengolah data, penulis menggunakan teori Miles dan Huberman, yaitu: reduksi data, display data, dan verifikasi data Guna memeriksa keabsahan data. Adapun perincian dari teknik di atas adalah sebagai berikut

1. Keterpercayaan (credibility)
a. Trianggulasi
b. Pembahasan Sejawat
c. Memperpanjang keikutsertaan

2. Keteralihan (transferability)

3. Kebergantungan (dependability)

4. Kepastian (confirmability)

\section{EKSISTENSI MEDIA SOSIAL TERHADAP PERILAKU SISWA SMP 1 NEGERI DI KECAMATAN BELOPA UTARA.}

Teknologi dapat menciptakan lingkungan pergaulan sosial yang tidak sehat, seperti menimbulkan gap antara kelompok anak yang menggunakan teknologi dan kelompok anak yang tidak menggunakan teknologi. Ketika keluar gadget terbaru yang lebih canggih, banyak anak meminta kepada orang tua, padahal mereka sebenarnya belum memahami benar manfaat setiap fitur-fitur baru secara menyeluruh. siswa akan sulit diawasi, khususnya ketika masa-masa pubertas, disaat sudah muncul rasa ketertarikan dengan teman lawan jenis, maka teknologi menjadi sarana ampuh bagi mereka untuk komunikasi, tetapi komunikasi yang tidak baik, hal ini akan mengganggu aktifitas yang seharusnya mereka lakukan seperti shalat, makan, belajar bahkan tidur.

Hasil wawancara dengan guru di SMP Negeri 1 Belopa menyatakan bahwa: "Siswa yang membawa HP ke sekolah cenderung kurang berkonsentrasi dalam pelajaran. Mereka cenderung melamun saat pelajaran berlangsung. Ketika dipanggil, atau ditanya tidak langsung menjawab. Hal tersebut dimungkinkan karena efek dari seringnya bermain HP pada siswa."17

Hasil wawancara dengan guru PAI di SMP Negeri 1 Belopa, menyatakan bahwa:

"Sebagian besar siswa memang membawa HP ke sekolah. Kadang terjadi semacam gank pada siswa yang membawa HP dan yang tidak. Mereka yang membawa HP juga enggan untuk meminjamkan pada teman yang tidak memiliki. Jadi sangat diperlukan pengawasan dan imbauan oleh guru bahwa teknologi dilarang dibawa ke sekolah. Meski peraturan demikian sudah diberikan, namun masih saja siswa membaca media sosial ke sekolah."18

\footnotetext{
${ }^{17}$ Mardiati , Guru SMP Negeri 1 Belopa, wawancara, 11Oktober 2016.

${ }^{18}$ A. Juara, Guru SMP Negeri 1 Belopa, wawancara, di Belopa, 11 Oktober 2016.
} 
Hasil penelitian menunjukkan bahwa terdapat karakter antara siswa yang menggunakan HP dan tidak menggunakan teknologi di SMP Negeri Belopa yang tidak memiliki teknologi dalam kategori baik atau lebih tinggi dibandingkan dengan siswa yang memiliki teknologi dalam kategori cukup.

Dikemukakan oleh guru dari SMP Negeri 1 Belopa bahwa:

"Memang anak yang membawa HP dan yang tidak membawa teknologi terlihat berbeda. Mereka yang membawa teknologi selalu sibuk dengan teknologi-nya, sehingga ketika dipanggil oleh guru mereka tidak memperhatikan. Ketika diberikan tugas, mereka tidak langsung mengerjakan. Ketika diberi pertanyaan tidak memperhatikan, sehingga guru harus mengulang pertanyaan pada siswa."19

Salah satu informan dalam penelitian ini yang rata-rata menggunakan media sosial selama 2 jam dalam satu hari mengatakan bahwa dia menggunakan media sosial sekedar untuk berhubungan dengan teman atau mencari tahu tentang informasi:

"Kalau untuk saat ini saya lebih sering menggunakan media sosial sebagai sarana untuk mencari tahu, Pak. Karena kan saya juga menyadari bahwa saat ini saya adalah siswa baru yang belum sepenuhnya memahami tentang sistem belajar di sini".

Sedangkan dalam konteks penggunaan media sosial sebagai sarana untuk eksistensi, dia mengatakan:

"Eksistensi, saya sebenarnya belum begitu paham tentang itu, pak. Kalau maksudnya eksistensi adalah untuk sekedar pamer foto atau kalau istilahnya dalam Path, untuk check in ditempat tempat terkenal, saya terkadang risih juga pak"20

Informan kedua adalah siswa, yakni Indah. Dari wawancara yang dilakukan dengan informan kedua ini, peneliti mengetahui bahwa tujuan yang ingin didapatkan dalam menggunakan media sosial adalah untuk sarana berbagi foto maupun video.

"Saya sering menggunakan facebook untuk sarana berbagi foto maupun video Pak. Karena menurut saya, media sosial memang seharusnya digunakan untuk sarana berbagi. Ya menurut saya sah saja pak banyak posting foto di media sosial". ${ }^{21}$

\footnotetext{
${ }^{19}$ Mardiati, Guru SMP Negeri 1 Belopa, wawancara, di Belopa, 11 Oktober 2016.

${ }^{20}$ Silva, Siswa SMP Negeri 1 Belopa, wawancara, di Belopa, 14 Oktober 2016.

${ }^{21}$ Indah Nur Shabrina, Siswa SMP Negeri 1 Belopa, wawancara, di Belopa, 14 Oktober 2016.
} 
Penggunaan media sosial yang setiap hari rata-rata dia menggunakan media sosial selama 4 jam. Tentu hal tersebut memberikan gambaran tentang penggunaan media sosial yang bisa dikatakan di atas rata-rata. Informan juga mengatakan bahwa jika dihubungkan dengan permasalahan eksistensi, informan menjawab bahwa hal tersebut menjadi hak setiap pengguna media sosial dalam berekspresi melalui media sosial.

"Kan ga ada aturan yang ngatur masalah eksistensi. Jadi ya itu menurut saya jadi hak setiap orang pak. Kalau masalah orang suka atau tidak dengan apa yang kita lakuin, itu kembali ke pribadi masing-masing" ${ }^{22}$

Penjelasan serta pernyataan tentang pandangannya terhadap permasalahan eksistensi. Dimana menurutnya eksistensi menjadi hak setiap orang yang menggunakan media sosial. Eksistensi yang menjadi tujuan dalam menggunakan media sosial memang menjadi semacam dua sisi yang berbeda. Dimana pada sisi pertama eksistensi memang menjadi suatu bentuk sifat ingin mengekspresikan sesuatu. Sedangkan pada sisi lain mungkin menjadi hal yang tidak sepenuhnya memiliki tujuan yang jelas. Sementara itu pandangan lainnya disampaikan oleh, siswa yang menggunakan media sosial seperti instagram,.

"Kan setiap jenis media sosial sebenarnya memiliki karakteristik sendirisendiri. Misalnya kalau twitter itu efektif untuk mencari informasi, kemudian kalau instagram kan bisa untuk sarana melihat berbagai foto dan video. Nah kalau facebook kan karakteristiknya memang lebih untuk media mengekspresikan diri pak. Misalnya lewat path kita bisa berbagi video, foto maupun untuk check-in ke suatu tempat". ${ }^{23}$

Tatakrama dan tata tertib kehidupan sosial sekolah harus disandarkan pada tata nilai dasar yang meliputi ketaqwaan, sopan santun pergaulan, kedisiplinan/ketertiban, kebersihan, kesehatan, kerapian, keamanan, kejujuran, tanggung jawab, kebersamaan, keadilan, dan respek. Dari tata nilai dasar ini dikembangkan rambu-rambu yang disesuaikan dengan kultur dan lingkungan sekolah, dengan implementasi yang dikontrol secara cermat.

Kenakalan yang ada di SMP Negeri 1 Belopa memang beragam dari kenakalan berat dan kenakalan ringan di sebabkan oleh pengaruh HP. Hampir $90 \%$ siswa SMP Negeri 1 Belopa mempunyai HP Android. Kenakalan berat diprioritaskan pada siswa yang melakukan pelanggaran seperti berkelahi, mencuri, minum minuman keras disekolahan dan kenakalan-kenalan ringan yang sering dilakukan oleh siswa akan menjadi kenakalan berat dengan sanksi yang sudah ada. Kenakalan ringan yaitu kenakalan yang dilakukan oleh siswa seperti

\footnotetext{
${ }^{22}$ A. Ibnu, Siswa SMP Negeri 1 Belopa, wawancara, di Belopa, 14 Oktober 2016.

${ }^{23}$ Meiladi, Siswa SMP Negeri 1 Belopa, wawancara, di Belopa, 14 Oktober 2016.
} 
membuat gaduh didalam kelas, mengganggu teman belajar, terlambat dan lain sebagainya.

Banyak kenakalan yang disebabkan oleh HP seperti: halnya membolos yang dilakukan hampir setiap hari oleh siswa. Setelah ditelusuri perilaku menyimpang yang dilakukan oleh siswa tersebut dilatarbelakangi oleh keadaan yang membuatnya bosan pada lingkungan di sekolah, akhirnya muncul inisiatif membolos dan mencari hiburan lain guna pemuasan keinginan hatinya.

Guru PAI dituntut untuk bisa memberikan peran aktifnya dalam menanggulangi kenakalan siswa yang terjadi di SMP Negeri 1 Belopa. Selain memberikan pemahaman tentang mata pelajaran PAI guru PAI juga berperan dalam masalah penataan tingkah laku. Tujuan dari pemahaman tingkah laku tersebut adalah tingkah laku siswa harus sesuai dengan ajaran agama Islam baik dalam kehidupan di sekolah maupun di luar sekolah.

\section{FAKTOR-FAKTOR PENGHAMBAT GURU PAI DALAM MENGANTISIPASI DAMPAK MEDIA SOSIAL DI SMP NEGERI BELOPA UTARA}

Namun dari semua usaha yang dilakukan oleh para guru PAI yang ada di SMPN 1 Negeri di Kecamatan Belopa utara ini tidak semuannya berjalan mulus, ada beberapa kendala yang di hadapi oleh para guru PAI, di antaranya ialah :

1. Kurang dukungan orang tua siswa

Banyak orang tua siswa yang ada di SMPN 1 Negeri di Kecamatan Belopa Utara ada di antara mereka yang tidak ingin kerja sama dengan para guru-guru, tidak ingin kerja sama dalam artian mereka tidak terlalu aktif untuk memantau dan membimbing anak-anak mereka ketika mereka sudah kembali kerumah. Menurut Salma, salah satu hal yang membuat ini bisa terjadi karna para orang tua berfikir bahwa anak-anak mereka sekolah bukan lagi menggunakan uang mereka, tapi menggunakan uang pemerintah sehingga ada muncul bahasa di kalangan orang tua siswa mengatakan bahwa “tannia sia doi'ta napake massikola, doi'na sia pamarentah" dan hal inilah yang membuat sebagian orang tua siswa tidak terlalu khawatir atau peduli jika anak-anak mereka tidak terlalu fokus belajar, bahkan yang lebih parannya lagi sebagian orang tua tidak terlalu aktif dalam memantau anak-anak mereka, apakah anak-anak mereka betul-betul kesekolah atau justru anak mereka pergi berkeliaran pada saat jam sekolah. ${ }^{24}$

Namun para guru yang ada di SMPN Negeri 1 di Kecamatan Belopa Utara terkhusus para guru PAI tetap selalu berusaha untuk memberikan arahan dan pemahaman kepada para orang tua siswa yang masih berfikiran seperti itu, agar kedepannya semua orang tua siswa bisa diajak bekerja sama terkhusus dalam mengawasi anak-anak mereka ketika para siswa itu telah kembali kerumah mereka masing-masing.

\footnotetext{
${ }^{24}$ Salma, Guru PAI di SMP Negeri 1 Belopa, wawancara, di Belopa, 11 Oktober 2016.
} 


\section{Pengaruh dari lingkungan sekitar}

Lokasi SMPN 1 Negeri di Kecamatan Belopa Utara Kabupaten Luwu tepat berada di tempat keramaian yang hal ini membuat lingkungan sekitar sekolah menjadi tempat yang kurang kondusif bagi para siswa yang ada di SMPN Negeri 1 di Kecamatan Belopa Utara, apalagi pada saai ini orang-orang yang berada di sekitar sekolah telah memperlihatkan tingkah laku yang kurang baik untuk di contoh, dan hal ini sangat berpengaruh bagi para siswa, karena apa yang terjadi di lingkungan sekitar sekolah dan lingkungan di umumnya bisa disaksikan oleh para siswa secara live, contoh kecilnya, ketika ada beberapa anak muda yang nongkrong di sekitar lingkungan sekolah dan mereka sedang bersama dengan pasangan mereka masing-masing, yang hal ini bisa disaksikan langsung oleh para siswa, belum lagi ketika orang-orang yang berlalu lalang di sekitar sekolah itu mengisap rokok dengan bebasnya, tentu ini akan terekam dibenak para siswa dan mereka akan penasaran untuk ikut mencobanya, mereka tinggal menunggu dan mencari kapan waktu yag tepat untuk melakukan hal-hal yang seperti itu, dan di sinilah salah satu fungsi dari program-program yang dibuat oleh para guru PAI yang ada di SMPN 1 Negeri di Kecamatan Belopa Utara. ${ }^{25}$

Beberapa masalah yang dialami oleh para guru yang ada di SMPN 4 Negeri di Kecamatan Belopa Utara terkhusus para guru PAI dalam upaya mereka mencegah agar para siswa itu dengan mandirinya bisa menjaga diri mereka sendiri dari hal-hal negatif yang bisa ditimbulkan oleh teknologi dan dari permasalahan ini pula, para guru PAI tetap berusaha untuk memperbaiki dan mencari solusi atas masalah-masalah yang mereka hadapi terkhusus dalam masalah dampak negatif yang bisa ditimbulkan oleh teknologi dan hal tersebut menjadi tantangan dan motivasi tersendiri bagi para guru-guru PAI yang ada SMPN 4 Negeri di Kecamatan Belopa Utara dalam upaya mereka untuk menjawap tantangan akhir zaman yang banyak merisaukan masyarakat terkhusus para umat muslim.

Situasi yang serba terbuka saat ini akan menyulitkan para guru dan orang tua untuk mengambil langkah-langkah preventif yang efektif sekalipun. Potensi merusak dari teonologi komunikasi semacam teknologi, akan melunturkan nilainilai tradisi dan budaya. Selama ini dampak teknologi yang mempertontonkan adegan-adegan mesum relatif dapat dilokalisir, namun kehadiran teknologi mengakibatkan tayangan-tayangan pornografi dan pornoaksi dapat dengan mudah menyusup ke ruang-ruang privasi tanpa dapat dikontrol lagi.

Masing-masing aspek tersebut hendaknya memuat beberapa kegiatan yang harus diperhatikan oleh siswa, dan staf sekolah. Aturan yang ditegakkan sematamata dimaksudkan untuk menciptakan kultur sekolah yang kondusif bagi perkembangan jiwa siswa secara utuh. Sekolah sebagai lembaga pendidikan hendaknya mampu membentuk kepribadian yang luhur melalui penanaman

\footnotetext{
${ }^{25}$ Hasniar, Guru SMP Negeri 1Belopa, wawancara, di Belopa, 11 Oktober 2016
} 
kebiasaan cara hidup dan berperilaku, serta menegakkan tata nilai yang diakui secara universal.

Minimnya contoh ini tentu bukan saja akibat kurangnya kesadaran, tapi bisa juga akibat tidak tersedianya sarana dan prasarana yang ikut mendukung. Sulitnya membuang sampah pada tempatnya, banyak yang diakibatkan tidak tersedianya bak sampah. Banyaknya yang buang kotoran pada sembarang tempat, akibat tidak memadainya sarana yang diperlukan, atau kurangnya perawatan fasilitas. Demikian pula teguran dan kecaman pada sesama yang berbuat kekeliruan berakibat bebasnya dan terbiasanya melakukan sesuatu kekeliruan yang sesungguhnya tidak perlu. ${ }^{26}$

Dapat dipahami bahwa tantangan Pendidikan Agama Islam yang begitu kompleks pada dasarnya dapat dikelompokkan ke dalam dua macam, yaitu tantangan internal dan tantangan eksternal dari Pendidikan Agama Islam. Tantangan intenal menyangkut sisi Pendidikan Agama sebagai program pendidikan, baik dari segi orientasi Pendidikan Agama Islam yang kurang tepat sempitnya pemahaman terhadap esensi ajaran Agama Islam perancangan dan penyusunan materi yang kurang tepat, maupun metodologi dan evaluasinya, serta pelaksanaan dan penyelenggaraan Pendidikan Agama Islam itu sendiri yang sebagiannya masih bersikap eksklusif dan belum mampu berinteraksi dan bersinkronisasi dengan yang lainnya.

Tantangan eksternal berupa berbagai kemajuan ilmu pengetahuan dan teknologi yang berdampak pada munculnya scientific critizism terhadap penjelasan ajaran agama yang bersifat konservatif, tradisional, tekstual, dan skripturalistik; era globalisasi di bidang informasi serta perubahan sosial ekonomi dan budaya dengan segala dampaknya dan kemajemukan masyarakat beragama yang masih belum siap untuk berbeda paham dan justru cenderung bersikap apologis, fanatik, absolutis, serta truts claim yang dibungkus dalam simpul-simpul interest, baik interes pribadi maupun yang bersifat politis atau sosiologis.

Berbagai macam tantangan Pendidikan Agama Islam tersebut sebenarnya dihadapi oleh semua pihak, baik keluarga, pemerintah, maupun masyarakat, baik yang terkait langsung ataupun tidak langsung dengan kegiatan pendidikan agama Islam. Namun demikian, GPAI di sekolah yang terkait langsung dengan pelaksanaan pendidikan Islam dituntut untuk mampu menjawab dan mengantisipasi berbagai tantangan tersebut. Untuk mengantisipasinya diperlukan adanya profil GPAI di sekolah yang mampu menampilkan sosok kualitas personal, sosial, dan profesionalisme dalam menjalankan tugasnya.

\section{PENUTUP}

Siswa SMP 1 Negeri Kecamatan Belopa Utara memanfaatkan media sosial sebagai ajang untuk menunjukkan keberadaan dirinya kepada dunia luar. Setiap

${ }^{26}$ Syarifuddin, Guru PAI di SMP Negeri 1 Belopa, wawancara, 12 Oktober 2016 
orang berlomba-lomba untuk menampilkan dan membuat branding tentang dirinya kepada dunia luar. Sedangkan SMP 4 Negeri berbagai foto, video, pernyataan yang ada di media sosial, seseorang ingin mengungkapkan kepada orang lain bahwa inilah dirinya. Tidak jarang pula bahkan seseorang bisa bertindak berlebihan untuk sekedar menunjukan eksistensi dirinya kepada orang lain.

Adapun yang menjadi penghambat guru PAI dalam mengantisipasi dampak media sosial di SMP Negeri Belopa Utara.

a. Kurang kerja sama guru dan orang tua dalam mengantisipasi penggunaan media sosial.

b. Lingkungan masyarakat (pergaulan) pergaulan dari siswa di luar sekolah juga sangat berpengaruh besar terhadap tingkah laku dan perilaku siswa dalam kehidupan sehari-hari.

c. Kurang efektifnya peraturan yang dibuat sekolah.

\section{DAFTAR PUSTAKA}

Alim, Muhammad, Pendidikan Agama Islam, Upaya Pembentukan Pemikiran dan Kepribadian Muslim, Bandung: Remaja Rosdakarya, 2006.

Arikunto, Suharsimi, Prosedur Penelitian Suatu Pendekatan Praktek, Jakarta: Rineka Cipta, 1998.

Bahri Djamarah, Syaiful, Prestasi Belajar dan Kompetensi Guru, (Surabaya: Usaha Nasional, 1994.

Baidhawy, Zakiyuddin, Pendidikan Agama Berwawasan Multikultural, Bandung: Pustaka Setia, 2005.

Christiany Juditha, "Hubungan Penggunaan Status Jejaring Sosial Facebook terhadap Perilaku Remaja di Kota Makasar", Jurnal Penelitian IPTEK-KOM, Vol 13 No. 1, Juni 2011, Yogyakarta: Kompasiana, 2001.

Copleston, Frederick, A History of Philosophy, London: Search Press and New Jersey, Paulist, 1946.

Departemen Agama RI, al-Qur'an dan terjemahnya, Surabaya, Diponegoro, 2010.

Depdikbud, Kamus Besar Bahasa Indonesia, Jakarta: Balai Pustaka, 1995.

Dugan, Robert B. dan Steven J. Taylor. Dasar-Dasar Penelitian Kualitatif, I; Surabaya: Usaha Nasional, 1993.

Dirjen Pendidikan Islam Kementerian Agama, UU dan Permen tentang Pendidikan, Jakarta: 2006.

Furqon Kholid, Setia, Jangan Kuliah! Kalau Gak Sukses, Sumedang, Rumah Karya, 2010.

Hidayatullah, M. Furqon, Guru Sejati: Membangun Insan Berkarakter Kuat dan Cerdas, Surakarta: Yuma Pustaka, 2010. 
Huda, Miftahul, Idealitas Pendidikan Anak, Malang: UIN Malang Press, 2009.

Isna Aunillah, Nurlah, Panduan Menerapkan Pendidikan Karakter di Sekolah, Jogyakarta: Laksana, 2011

Jaelani, Penyucian Jiwa (Tazkiyat al-Nafs) dan Kesehatan Mental, Jakarta: Amzah, 2000.

Kementerian Pendidikan Nasional Badan Penelitian dan Pengembangan Pusat Kurikulum dan Perbukuan, Pedoman Pelaksanaan Pendidikan Karakter, Berdasarkan Pengalaman di Satuan Pendidikan Rintisan, 2011.

Kharmim Zarkasyi Putro, Orang Tua Sahabat Anak dan Remaja, Yogyakarta, Cerdas Pustaka, 2005.

Labib, Etika Mendidik Anak menjadi Sholeh, Surabaya: Putra Jaya, 2007.

Lincoln, Y. S. \& Guba E. G, Naturalistic Inquiry, Beverly Hill: SAGE Publication. Inc, 1985.

Ma'arif, Syamsul, Pendidikan Pluralisme di Indonesia, Yogjakarta: Logung Pustaka, 2005.

Maksum, Ali, Paradigma Pendidikan Universal, Jakarta: Bumi Aksara, 2007.

Mahfud, Choirul, Pendidikan Multikultural, Bandung: Rosdakarya, 2007.

M. Subana dan Sudrajat, Dasar-Dasar Penelitian Ilmiah, Bandung: Pustaka Setia, 2005.

Majid dan Dian Andayani, Abdul, Pendidikan Karakter dalam Perspektif Islam, Bandung: Remaja Rosdakarya, 2011.

Madjid, Abd., Tantangan dan Harapan Umat Islam di Era Globalisasi, Bandung: Pustaka Setia, 2000.

Muhaimin, Nuansa Baru Pendidikan Islam, Jakarta: Raja Grafindo Persada, 2006.

Mulyasa, Menjadi Guru Profesional Menciptakan Pembelajaran Kreatif dan Menyenangkan, Bandung: Remaja Rosdakarya, 2013.

Margono, S., Metodologi Penelitian Pendidikan, Jakarta: Rineka Cipta, 2003.

Moleong, Lexy, Metodologi Penelitian Kualitatif, Bandung: Remaja Rosda Karya, 2012.

Narwanti, Sri, Pendidikan Karakter Pengintegrasian 18 Nilai Pembentuk Karakter dalam Mata Pelajaran, Yogyakarta: Familia, 2011.

Nata, Abuddin, Manajemen Pendidikan Mengatasi Kelemahan Pendidikan Islam di Indonesia, Jakarta: Prenada Media, 2007.

Nasution S, Memahami Penelitian Naturalistik Kualitatif, Bandung: Alfabeta, 1998.

Nikmah, "Dampak Penggunaan Cellularphone Terhadap Prestasi Siswa", E-Jurnal Volume 5, Surabaya: Dinas Pendidikan Kota Surabaya, 2013.

Nurjanah, Siti, Pengaruh Penggunaan Media Sosial Facebook terhadap Perilaku Cyberbullying pada Siswa SMAN 12 Pekan Baru, (Laporan Penelitian Ilmiah pdf, Jom FISIP Volum.1, No.2, Jurusan Ilmu Komunikasi-Prodi Ilmu 
Komunikasi-Fakultas Ilmu Sosial dan Politik UNIVERSITAS RIAU, 2014 , di akses pada 12 januari 2016.

Rahmad, Jalaludin, Psikologi beragama, Bandung: Mizan. 2002.

Rifai, Muhammad, Sosiologi Pendidikan, Yogjakarta: Ar-Ruzz Media, 2011.

Syamsi Basya, Hassan, Mendidik Anak Zaman Kita, Jakarta: Zaman, 2001.

Sukardi, Metodelogi Penelitian Kompetensi dan Praktiknya, Jakarta: Bumi Aksara, 2007.

Sugiyono, Memahami Penelitian Kualitatif, Bandung: Alfabeta, 2012.

Sztompka, Piotr, The Sociology of Social Change, diterjemahkan oleh Alimandan dengan judul: Sosiologi Perubahan Sosial, Jakarta: Prenada, 2007.

Tohirin, Psikologi Pembelajaran Pendidikan Agama Islam, (Jakarta: Raja Grafindo Persada, 2006.

Wahyu Pamungkas, Heru, Interaksi Orang Tua Dengan Anak Dalam Menghadapi Teknologi Komunikasi Internet (Studi Pada SMA Rahadi Usman), Jurnal Pontianak: Tesis PMIS Untan, 2014.

Zuriah, Nurul Panduan dan Aplikasi Pendidikan Karakter, Bandung: Yrama Widya, 2011.

Zubaidi, Desain Pendidikan Karakter konsepsi dan Aplikasinya dalam lembaga pendidikan, Jakarta: Prenada Media Group, 2011. 
120 | Ismail/ IQRO: Journal of Islamic Education Vol. 1, No.2, Desember 2018. 105-120

Halaman ini sengaja dikosongkan 